Vol. 1, No 2, Seri C, Mei 2019, Hal 740-750
ISSN : 2656-3649 (Online)

http://jea.ppj.unp.ac.id/index.php/jea/issue/view/7

\title{
SISTEM PENGENDALIAN MANAJEMEN DAN KEPEMIMPINAN PADA BISNIS KELUARGA ETNIS MINANGKABAU
}

\author{
Ayu Wandira', Sany Dwita², Erly Mulyani ${ }^{3}$ \\ 1)Alumni Jurusan Akuntansi Fakultas Ekonomi, universitas Negeri Padang \\ 2,3) Jurusan Akuntansi Fakultas Ekonomi, universitas Negeri Padang \\ *Korespondensi:ayuwdr@yahoo.com
}

\begin{abstract}
Abstrack: This study's purpose in this paper is to reveal the relationship between management control systems and leadership styles in the Minangkabau ethnic family business. By using an interpretive qualitative approach with the lens of ethical and emicent anthropology. Ethical views refer to outside interpretations (researchers and previous literature). The combination of these two views allows a deep understanding of this case. Interview, observation and documentary analysis used to collect data. and emik is how people interpret phenomena. The emic and ethical approaches are used to see how culture influences leadership styles and management control systems in Minangkabau ethnic family companies. Minangakabau is an ethnic that has special characteristics with the matrilineal system, namely the lineage drawn from the mother's side, and the leadership system known as tungku tigo sajarangan and with traditional jargon adat basandi syarak, syarak basandi kitabullah. The Minangkabau ethnic group is known for its culture of migrating and trading. The cultural background of the leader will determine how the management in the company, but the leader is not the only determinant in the formation of culture, but the leader adapts to the cultural conditions, with the same culture between leaders and employees, the organizational process will run better. The limitation in this study is that this research was only carried out on one Minangkabau ethnic family, so that it was unable toililize all the values applied by entrepreneurs from the Minangkabau ethnic group in the companies they owned.
\end{abstract}

Keyword : Leadership, Management Control System (MCS) and Minangkabau ethnic

\section{How to cite (APA $6^{\text {th }}$ style)}

Wandira, A., Dwita, S. \& Mulyani, E. (2019). Sistem Pengendalian Manajemen Dan Kepemimpinan Pada Bisnis Keluarga Etnis Minangkabau. Jurnal Eksplorasi Akuntansi, 1(2), Seri C, 740-750.

\section{PENDAHULUAN}

Pengendalian manajemen merupakan fungsi penting dalam organisasi. Kegagalan dalam pengendalian manajemen akan membawa kerugian finansial yang besar, rusaknya reputasi, bahkan mungkin dapat membawa kegagalan bagi organisasi. (Merchant, 2014,p. 5). 
Pengendalian manajemen adalah proses untuk mempengaruhi orang lain dalam sebuah perusahaan agar secara efektif dan efisien mencapai tujuan perusahaan (Anthony, 2005).

Merchant (2012) membedakan tiga jenis kontrol dalam sistem pengendalian manajemen yaitu pengendalian hasil, pengendalian tindakan, dan pengendalian personil. Pengendalian hasil biasanya digunakan untuk mengendalikan perilaku karyawan pada berbagai tingkatan organisasi dan juga memberikan manfaat dalam tipe pencegahan, pengendalian budaya merupakan bentuk paling langsung dari pengendalian manajemen karena meliputi pengambilan langkah-langkah tertentu untuk memastikan karyawan bertindak sesuai dengan keinginan perusahaan. Pengendalian hasil memiliki keterbatasan karena hanya fokus pada hasil dan tidak melihat proses maka disinilah peran manajemen proses untuk mengendalian setiap aktivitas. Penggunaan kontrol informal ditemukan telah menjadi lebih umum di negara-negara berkembang (Ansari, 1991). Dalam konteks Indonesia, desain dan implementasi sistem pengendalian manajemen tidak dapat dipisahkan dari konteks sosial negara termasuk sejarah, budaya dan sosialisasi politik dan faktor situasional lainnya (Efferin, 2007).

Dalam penelitian Chan (2001) dilakukan penelitian tentang bagaimana kontrol manajemen dilakukan di dua rumah tangga keluarga Cina yang terkemuka pada abad ke-18. Dalam penelitian tersebut menyajikan bukti bahwa akuntansi terlibat dalam pengambilan keputusan keluarga. Salah satu penelitian lainnya dilakukan oleh Ansari tahun 1991 yaitu penelitian yang dilakukan mengenai pengaruh budaya masyarakat pada praktik akuntansi dan kontrol dari bisnis keluarga Pakistan. Temuan penelitian ini menunjukkan bahwa selain tampilan ekonomi rasional, desain sistem akuntansi dan pengendalian dalam organisasi dapat dijelaskan dari perspektif budaya namum dalam penelitian diatas tidak ada dijelaskan kaitan dan fungsi kepemimpinan yang terkandung didalamnya. Mengingat pentingnya peran pemilik atau pemimpin dalam pelaksanaan sistem pengendalian manajemen. Efferin dan Hartono (2015) mengatakan bahwa sistem pengendalian manajemen adalah gaya kepemimpinan yang dibangun dalam sistem. Meskipun kepemimpinan melekat dalam desain dan pelaksanaan sistem pengendalian manajemen, sangat sedikit penelitian yang membahas topik ini dalam 20 tahun terakhir (Abernethy, 2010). Sedangkan sifat hubungan saling ketergantungan antara gaya kepemimpinan dan dasar budaya tidak dapat diabaikan atau diremehkan (Jogolu, 2009).

Gaya kepemimpinan adalah cara seorang pemimpim bersikap, berkomunikasi, dan berinteraksi dengan orang lain dalam mempengaruhi orang lain untuk melakukan sesuatu. Gaya tersebut bisa berbeda-beda atas dasar motivasi, kuasa ataupun orientasi terhadap tugas atau orang tertentu.( Nur, 2017 P,5). Karakter pribadi dari individu yang berada dalam kondisi budaya tertentu akan mendapatkan pengaruh dari lingkungan budaya dengan derajat yang berbeda, tergantung pada seberapa besar kegiatan individu dalam lingkungan budaya.

Penelitian ini merupakan lanjutan dari penelitian Efferin (2015) dan konsisten dalam struktur penelitiannya. Penelitian ini mencoba mengungkapkan bagaimana budaya terefleksi dalam penerapan sistem pengendalian manajemen dan kepemimpinan pada perusahaan keluarga etnis Minangkabau. Studi kasus dilakukan pada perusahaan "ABC" (nama disamarkan) yang berada Sumatera Barat. Mengapa peneliti mengambil perusahaan "ABC" karena dalam penelitian Efferin memiliki setidaknya tiga keterbatasan potensial yang menjamin penelitian lebih lanjut. Pertama, bisnis keluarga yang diteliti Efferin (2015) masih dijalankan oleh pendirinya sehingga dampak dari suksesi pada budaya organisasi Kedua, perusahaan tidak memiliki anak. Beberapa anak mungkin memiliki subkultur mereka sendiri yang sampai batas tertentu, mungkin berbeda dari kantor pusat ini. Ketiga, budaya mungkin berbeda mempengaruhi kepemimpinan dan system pengendalian manajemen. 
Penelitian ini pertama kali dilakukan oleh Tsamenyi (2007) studi ini melihat sistem pengendalian manajemen diterapkan pada bisnis keluarga dalam konteks negara berkembang studi kasus dilakukan pada Universitas swasta di Indonesia yang dimiliki oleh keluarga jawa. Dari penelitian Tsamenyi kontrol informal yang berasal dari nilai-nilai pribadi pemilik dan budaya masyarakat dari masyarakat sekitarnya, terutama terdiri dari tiga nilai Jawa: bapakism (paternalisme dan patronase), rukun (pengambilan keputusan kolektif, keputusan bulat, kerjasama) dan pakewuh ewuh (keengganan antara atasan non-keluarga untuk menghukum bawahan yang memiliki hubungan dengan keluarga). Akibatnya, nilai-nilai ini menjadi ideologi dengan legitimasi tertinggi dimiliki oleh semua anggota organisasi mengatasi alat kontrol manajemen yang diimplementasikan dalam organisasi.

Salah satu penelitian lainnya dilakukan oleh Ansari dan Bell (1991) yaitu penelitian yang dilakukan mengenai pengaruh budaya masyarakat pada praktik akuntansi dan kontrol dari bisnis keluarga Pakistan. Temuan penelitian ini menunjukkan bahwa selain tampilan ekonomi rasional, desain sistem akuntansi dan pengendalian dalam organisasi dapat dijelaskan dari perspektif budaya. Namun dalam penelitian diatas tidak ada dijelaskan kaitan dan fungsi kepemimpinan yang terkandung didalamnya. Mengingat pentingnya peran pemilik atau pemimpin dalam pelaksanaan sistem pengendalian manajemen. pemilik atau pemimpin dalam pelaksanaan sistem pengendalian manajemen.

Penelitian dari sisi kepemimpinan dilakukan oleh Abernerthy (2010) melakukan penelitian berbasis kuesioner dan mengusulkan model untuk menilai efek dari gaya kepemimpinan pada tiga unsur sistem pengendalian manajemen, yaitu: pilihan delegasi, perencanaan dan sistem kontrol, dan sistem pengukuran kinerja. Studi ini menunjukkan bahwa kepemimpinan secara signifikan dapat memprediksi pelaksanaan perencanaan dan pengendalian sistem dan sistem pengukuran kinerja. Namun penelitian ini tidak fokus pada bisnis keluarga. Penelitian lainnya dilakukan oleh Hanif (2015) Penelitian ini dimaksudkan untuk menggali nilai-nilai budaya yang mendasari desain sistem pengendalian manajemen perusahaan dengan menggunakan paradigma interpretif, metode etnografi adalah melaksanakan untuk mengeksplorasi makna budaya pada rumah makan etnis Minangkabau. Desain sistem pengendalian manajemen pada organisasi GRPXJ dipengaruhi oleh faktor eksternal dan internal. Lingkungan eksternal meliputi budaya di mana aktor utama sangat berpengaruh dalam organisasi, dan kemudian berinteraksi dan nilai-nilai bentuk di dalamnya. Sistem pengendalian manajemen diperngaruhi oleh TTS (Tungku Tigo Sajarangan) dan Adat Basandi Syarak, Syarak Basandi Kitabullah. Dimana hal ini terlihat dari sistem akuntansi yang dipengaruhi kuat oleh nilai syariah. Secara umum sistem pengendalian manajemen dipengaruhi oleh sistem tradisional dan modern karena usaha yang diteliti berada di kota Jakarta.

Penelitian selanjutnya dilakukan oleh Efferin dan Hopper tahun 2015 tentang pengendalian manajemen dan gaya kepemimpinan dalam bisnis keluarga etnis China yang ada di Indonesia, dalam penelitian tersebut mendukung studi Ansari (1991) dan Tsamenyi (2008) bahwa budaya masyarakat menjadi pusat sistem pengendalian manajemen dalam sistem pengendalian manajemen pada perusahaan keluarga, namun berbeda dari dua studi tersebut yang menyoroti kontrol formal dan kontrol informal. Penelitian efferin menemukan bahwa tidak ada dikotomi antara kontrol formal dan kontrol informal karena perusahaan keluarga yang diteliti menggunakan secara bersamaan antara kontrol formal sekaligus kontrol informalnya. Penelitian ini dilakukan pada bisnis keluarga etnis China di Surabaya, pada prusahaan yang bergerak pada kontruksi.

Penelitian ini merupakan lanjutan dari penelitian Efferin (2015) dan konsisten dalam struktur penelitiannya. Penelitian ini mencoba mengungkapkan bagaimana budaya terefleksi dalam penerapan sistem pengendalian manajemen dan kepemimpinan pada perusahaan keluarga 
etnis Minangkabau. Studi kasus dilakukan pada perusahaan "ABC" (nama disamarkan) yang berada Sumatera Barat. Usaha ini didirikan pada tahun 1980 oleh ibu "D" (nama disamarkan) pendiri utama perusahaan, setahun setelah itu ibu "D" menyerahkan usaha ini kepada anaknya ibu "S" yang merupakan generasi kedua perusahaan ini dan sekarang sedang terjadi proses suksesi kepemimpinan kepada ibu "Y" sebagai generasi ketiga yang merupakan anak dari ibu "S".

\section{REVIU LITERATUR DAN HIPOTESIS Sistem Pengendalian Manajemen}

Sistem pengendalian manajemen adalah sebuah realitas sosial perusahaan diciptakan melalui pengalaman dan pikiran manusia (Hanif, 2015). Pengendalian manajemen didefinisikan sebagai sistem dalam lingkungan sosial, budaya, politik dan ekonomi yang digunakan oleh manajemen untuk menyelaraskan perilaku karyawan dengan tujuan organisasi dan untuk mengelola saling ketergantungan antara internal dan ekternal (efferin, 2007).

\section{Sistem Pengendalian Manajemen dinegara berkembang}

Konteks Indonesia, desain dan implementasi sistem pengendalian manajemen tidak dapat dipisahkan dari konteks sosial negara termasuk sejarah, budaya dan sosialisasi, politik, dan faktor situasional lainnya (Efferin, 2007). Ansari dan Bell (1991) berpendapat bahwa sistem pengendalian manajemen terdiri dari sistem kontrol formal dalam negara berkembang hanya diperlukan untuk melegitimasi organisasi dengan pihak eksternal perusahaan. Aturan dan peraturan formal hanya memainkan peran seremonial. Dalam hal ini sistem pengendalian manajemen perlu dipahami tidak hanya sebagai sebuah kesamaan dari proses ekonomi yang rasional, tetapi juga sebagai proses sosial-budaya, dengan kearifan lokal bertindak sebagai panduan untuk berkomunikasi mengenai target, untuk mengidentifikasi tugas individu, untuk memantau kegiatan, untuk menetapkan imbalan dan hukuman dan untuk membangun keselarasan tujuan. (Efferin, 2016).

\section{Unsur Sistem Pengendalian Manajemen}

Berdasarkan Merchant (2012) sistem pengendalian manajemen terdiri dari pengendalian proses, pengendalian hasil dan pengendalian budaya.

\section{Pengendalian hasil}

Pengendalian hasil biasanya digunakan untuk mengendalikan perilaku karyawan pada berbagai tingkatan organisasi. Apabila sistem pengendalian hasil didesain dengan baik dapat membantu mendapatkan hasil yang diinginkan (Merchant, 2012). pengendalian hasil mengurangi potensi kurangnya pengarahan. Pengendalian hasil terdiri dari: Mendefinisikan dimensi kinerja. Mendefinisikan dimensi kinerja yang diinginkan dipilih karena tujuan yang ditentukan dan pengukuran yang dibuat akan membentuk karyawan mengenai hal yang dianggap penting, dimana sekarang pengukuran kinerja diartikan sebagai laba akuntansi. Pengaturan target kinerja dan pengukuran kineja dan Pemberian imbalan.

\section{Proses Pengendalian}

Pengendalian proses merupakan peran strategis dalam memastikan keberhasilan dalam pengendalian hasil. Terdiri dari : Struktur Organisasi, Sistem Reward dan Punisment Presedur Keuangan dan Akuntansi 


\section{Pengendalian Budaya Perusahaan}

Terdiri dari pengendalian tindakan, adalah bentuk paling langsung dari pengendalian manajemen karena meliputi pengambilan langkah-langkah tertentu untuk memastikan karyawan bertindak sesuai dengan keinginan perusahaan dengan membuat tindakan karyawan sendiri sebagai faktor pengendalian. Seleksi Karyawan baru, Sesi Pelatihan, Seleksi Karyawan baru Seleksi karyawan sering meliputi pengencekan referensi terhadap karyawan baru, Sesi Pelatihan Pelatihan adalah cara umum untuk meningkatkan kemungkinan karyawan melakukan pekerjaan dengan baik Kode Etik Kebanyakan perusahaan dengan ukuran diatas minimal berupaya untuk membentuk budaya perusahaan mereka melalui kode tingkah laku, kode etik, pernyataan misi, visi ataupun filosofi manajemen, Pengaturan fisik dan social. Pengaturan fisik seperti rencana kantor, arsitektur dan dekor interior, serta pengaturan sosial seperti kode penggunaan baju, kebiasaan yang dilembagakan, perilaku, dan kosa kata yang dapat membantu perusahaan.

\section{Gaya Kepemimpinan}

Kepemimpinan adalah proses mempengaruhi orang lain untuk memahami dan setuju tentang apa yang perlu dilakukan dan bagaimana melakukannya, dan proses memfasilitasi upaya individu dan upaya kolektif untuk mencapai tujuan bersama (Yukl, 2010). Penggalian nilai-nilai yang mendasari desain sistem pengendalian manajemen dalam akar sosial dan budaya yang membentuk nilai-nilai budaya perlu dilakukan untuk membentuk konsep sistem pengendalian manajemen.

Kepemimpinan merupakan bagian penting dari sistem pengendalian manajemen. Sedangkan, sifat saling tergantung antara gaya kepemimpinan dan dasar budaya tidak dapat diabaikan (Jogulu, 2010). Selain itu House (1971) menyatakan seorang pemimpin dapat menunjukkan lebih dari satu gaya kepemimpinan, dan mengidentifikasikan tujuh gaya kepemimpinan, yaitu: Kepemimpinan yang mengarahkan (kepemimpinan direktif). Kepemimpinan Supportif. Kepemimpinan Partisipatif. Kepemimpinan yang berorientasi pada pencapaian/kepemimpinan prestasi( kepemimpinan ini mendorong karyawan untuk berprestasi pada tingkat tertinggi mereka). Kepemimpinan Otoriter (merupakan gaya kepemimpinan yang memusatkan segala keputusan dan kebikan yang diambil dari dirinya sendiri secara penuh, Kepemimpinan Demokratis (pemimpin yang memberikan wewenang secara luas kepada para bawahan, setiap pengambilan keputusan selalu mengikutsertakan karyawan) Kepemimpinan Bebas (kepemimpinan anya terlibat pada kuantitas yang kecil).

\section{Budaya Minangkabau}

Masyarakat Minangkabau terkenal dengan budaya kolektif nya, yaitu adanya kebersamaan dan kekompakan dalam masyarakat. (Yulanda, 2015). Penelitian lain dilakukan oleh Hanif (2015) mengenai sistem pengendalian manajemen pada bisnis rumah makan Padang. Nilai-nilai budaya Minang sangat mempengaruhi gaya kepemimpinan dalam perusahaan tersebut. Nilai-nilai yang mempengaruhi yaitu nilai Tungku Tigo Sajarangan dan nilai-nilai Adat Basandi Syarak, Syarak Basandi Kitabullah. Nilai TTS diterapkan diantaranya adalah demokratis dimana siapapun bisa menghubungi dan berkomunikasi dengan pimpinan sesuai dengan jargon adat tagak samo tinggi, duduak samo randah, serta kepemimpinan yang menyesuaikan dan lebih fleksibel dalam menghadapi kondisi (dimaa bumi diinjak, disitu langik dijunjuang) serta penerapan disiplin yang baik. Nilai ABSSBK kiterapkan dengan cara diantaranya adalah pembayaran zakat secara rutin. 
(1) secara lokal, nilai-nilai Minangkabau dengan kepemimpinan berdasarkan nilai-nilai Tigo Tungku Sajarangan (TTS) (egaliter, kesetaraan, demokratis); adat bersendi syarak, syarak bersendi kitabullah (praktek ABSSBK, nilai-syariah).

\section{METODE PENELITIAN}

Penelitian ini menggunakan pendekatan kualitatif dengan paragdima interpretatif yang menggunakan lensa antropologi pandangan emik dan etik. Pandangan emik berasal dari interpretasi subyek perusahaan. Pandangan etik mengacu pada interpretasi dari luar (peneliti dan literatur sebelumnya) (Efferin, 2016). Agar meminimalkan bias peneliti, triangulations dilakukan dengan membandingkan hasil wawancara, pengamatan dan dokumentasi analisis untuk memeriksa konsistensi atau kontradiksi dari data (Neuman, 2011; Denzin, 1989). Penelitian ini dilakukan pada perusahaan keluarga "ABC" (nama disamarkan).

Perusahaan memiliki 2 cabang usaha dan 1 kantor pusat yang semuanya berlokasi di kota Payakumbuh, Sumatera Barat. Pemilihan subyek penelitian dilakukan dengan menggunakan metode pusposif sumpling. Tekhnik pengumpulan data utama dalam penelitian ini adalah wawancara semi-terstruktur dan observasi serta analisis dokumen sebagai pelengkap dan pembantu. Sesuai dengan karakteristik data yang diperlukan dalam penelitian ini. Analisis data pada penelitian ini, mengikuti proses yang dilakukan pada penelitian terdahulu yaitu penelitian Efferin (2015). Semua data yang diperoleh dari wawancara, observasi dan analisis dokumenter awalnya dikodekan ke dalam enam kategori utama: pengalaman masa kecil Mrs M, alasan untuk membangun perusahaan "ABC", nilai-nilai pribadi, gaya kepemimpinan, dan sistem pengendalian manajemen (pengedalian hasil, proses pengendalian dan pengendalian budaya). Kode awal dilakukan sesuai dengan isu-isu teoritis utama.

\section{PEMBAHASAN}

\section{Latar Belakang Perusahaan ABC dan Prinsip Pemiliki Perusahaan}

Perusahaan $\mathrm{ABC}$ adalah perusahaan yang bergerak pada produksi dan penjualan makanan khas Minangkabau yang sudah berdiri lebih dari 35 tahun dan beradara di kota Payakumbuh, Sumatera Barat. Sumatera barat terkenal dengan makanan khasnya dan salah satu daerah pusat usaha ini berada di kota Payakumbuh kota. Perusahaan ABC didirikan pertama oleh ibu "S" yang merupakan mertua dari ibu "D" . Hingga akhirnya pada tahun $1985 \mathrm{ibu}$ "S" memberikan usaha ini kepada menantunya yaitu ibu " $D$ ". Perusahaan $A B C$ memilki 1 toko sekaligus tempat produksi sebagai pusat usaha, cabang kedua toko serta juga tempat produksi kedua, dan tempat ketiga merupakan toko untuk penjualan. Pada akhir tahun 2018 memilki total karyawan 50 orang pegawai tetap belum termasuk karyawan musiman bulan tertentu.dengan omset pertahunnya paling sedikit 10 miliyar. Saat ini perusahaan $\mathrm{ABC}$ sedang mengalami masa suksesi dari generasi kedua (ibu D) kegenerasi ketiga (ibu C) yang merupakan putri kedua dari ibu D.

\section{Latar Belakang Pribadi}

Ibu "C" menganut agama Islam dengan pengaruh kuat dari nilai-nilai adat Minangkabau, pendidikan terakhir ibu $\mathrm{C}$ adalah sarjana jurusan agama merupakan anak kedua dari 8 bersaudara. Menurut ibu "C" apa yang dimiliki nya saat ini merupakan titipan dari Allah, sehingga dia memiliki kewajiban untuk menjaga baik karyawan maupun kelancaran usahanya, dengan cara menjaga keharmonisan dengan sistem kekeluargaan, lemah lembut, dan menjadi panutan dalam masyarakat. Ini merupakan nilai-nilai pribadi dari ibu"C" yang kemudian menjadi dasar dalam kepemimpinannya dalam organisasi/perusahaan. Selain itu, ibu " $\mathrm{C}$ " juga mendorong 
terutama wanita untuk memiliki usaha yang bisa menghasilkan dan tetap memiliki waktu untuk bersama keluarganya dirumah. Karena, dalam pandangan ibu " $C$ " sangat penting untuk seorang wanita tetap menjadi madrasah bagi anak-anak dirumah.

" kelancaran usaha ini bagi saya adalah atas keberkahan dari Allah, karena banyak keluarga yang hidup dari usaha ini” (ibu C)

Kepercayaan ini diterapkan ibu "C" sesuai dengan pepatah Minangkabau yaitu Adat Basandi Syarak, Syarak basandi Kitabullah, ketika bersikap kepada masyarakat dalam pengambilan keputusan dan semua yang berkaitan dengan kehidupan berasal dari keyakinan bahwa semua atas izin Allah.

\section{Gaya Kepemimpinan}

Gaya kepemimpinan yang diterapkan oleh ibu " $C$ " adalah gaya kepemimpinan suportif dan pastisipatif. Gaya kepemimpinan suportif merupakan kepemimpinan yang menunjukkan kepedulian terhadap kesejahteraan dan kebutuhan karyawan, sikap ramah serta memperlakukan karyawan seperti keluarga sendiri. Pada perusahaan ABC bentuk usaha berupa perusahaan keluarga sehingga gaya kepemimpinan suportif sangat diperlukan untuk menjaga jalannya usaha serta tetap menjaga kehangatan dalam ikatan keluarga. Apabila ada karyawan yang bermasalah maka pendekatan penyelesaian yang dilakukan oleh ibu " $\mathrm{C}$ " adalah dengan cara mengajarkan dan memahamkan karyawannya bahwa apa yang mereka lakukan adalah salah tetapi tetap dengan cara kekeluargaan.

Hal ini dilakukan ibu " $\mathrm{C}$ " karena hampir sebagian besar karyawannya memiliki umur yang lebih tua dari dirinya maka ibu $\mathrm{C}$ menerapkan konsep "tagak samo tinggi, duduak samo randah" dalam berhadapan dengan karyawannya dimana dia juga berpandangan bahwa bahkan dirinya juga memiliki kesalahan baik sebagai orang yang bertanggung jawab atas karyawannya baik dari segi mengayoman. Pembagian kerja dan jenis perkerjaan yang dilakukan dalam perusahaan ABC-pun sesuai dengan kemampuan masing-masing karyawannya, yaitu pada pekerjaan pembuatan galamai pekerja nya adalah laki-laki karena merupakan pekerjaan berat, dan untuk beberapa cabang pabrik seperti pada cabang kedua ibu "C" memberi keluasan kepada karyawan untuk produksi dirumah masing-masing peralatan dibelikan dan bahan baku diantarkan kerumah masing-masing karyawan dan hal ini dilakukan pada karyawan wanita yang biasanya karena mereka tidak bisa meninggalkan keluarganya ketika bekerja, karena kondisi ini disesuaikan dengan sifat masyarakat setempat (dimaa langik dijunjuang disinan bumi diinjak)

\section{Sistem Pengendalian Manajemen pada perusahaan "ABC" 1. Pengendalian Hasil}

\section{a. Menentukan ukuran kerja masing-masing karyawan}

Pendeskripsian dimensi kerja dalam perusahaan "ABC" berbeda antara satu karyawan dengan karyawan lainnya, hal ini dilakukan berdasarkan tingkat kepercayaan dan lama bekerja serta jenis pekerjaan yang dilakukan. Pada pekerjaan memasak galamai pekerjaan dilakukan hanya fokus pada memasak, untuk pengemasan ada karyawan lain yang melakukan, jenis produksi untuk batiah, karyawan yang bekerja bagian ini melakukan pekerjaan mulai dari proses produksi awal hingga pengemasan akhir. Sedangkan, bagian administrasi pada perusahaan pusat hanya fokus kepada administrasi karena banyak nya pekerjaan yang dilakukan setiap hari terutama untuk pencatatan bagian produk masuk dan keluar, bagian pekerjaan lain yaitu pada perusahaan 
cabang pada perusahaan ini untuk produksi dilakukan dengan cara kinerja ditentukan dari awal produksi hingga pengemasan namun pada bagian administrasi dan penjagaan toko salah satu karyawan yang merupakan karyawan kepercayaan pemilik bisa melakukan hampir seluruh jenis kerja kecuali produksi.

Dimensi kerja yang diterapkan pada perusahaan ABC pada umumnya bersifat kekeluargaan dan berdasarkan target. Sehingga, masing-masing karyawan sudah mengerti dengan ukuran kerja masing-masing karena akan berdampak pada imbalan yang akan mereka terima.

\section{b. Target Kinerja}

Target kinerja merupakan elemen penting dalam pengendalian hasil karena mempengaruhi tindakan, Pada perusahaan ABC penyelesaian tugas dibagi menjadi dua. Pertama, penyelesaian tugas berdasarkan target setiap hari, pengukuran ini biasa digunakan pada karyawan bagian produksi, dimana target pekerjaan yang mereka selesaikan akan menentukan berapa gaji yang akan mereka terima, sedangkan untuk bagian administrasi dan kantor target kinerja ditentukan dengan jam kerja yang mereka lakukan.

\section{c. Pemberian Imbalan}

Pemberian imbalan merupakan bentuk penilaian hasil yang diperoleh serta dapat mempengaruhi karyawan. Pada perusahaan ABC pemberian imbalan dibagi menjadi dua jenis. Pertama, karyawan bagian produksi. Pada bagian produksi mereka diberi imbalan berdasarkan berapa banyak pekerjaan yang mereka lakukan setiap hari nya dan setiap hari mereka memiliki target produksi masing-masing. Sedangkan, pemberian imbalan pada bagian administrasi dan kantor dihitung berdasarkan jam kerja yang telah ditetapkan, bukan berdasarkan target pekerjaan. Pemberian imbalan atau pemberian gaji pada perusahaan $\mathrm{ABC}$ biasa dilakukan sekali dalam seminggu.

\section{Pengendalian Budaya}

\section{a. Seleksi karyawan baru}

Perekrutan karyawan baru pada perusahaan "ABC" adalah dengan sistem jaringan keluarga, tenaga kerja paling banyak adalah keluarga yang berada disekitar tempat usaha berdiri yang merupakan rumah kediaman pemilik usaha, ketika membutuhkan karyawan baru maka karyawan akan membawa keluarga lainnya untuk ikut bekerja.

\section{b. Sesi pelatihan}

Sesi pelatihan untuk setiap karyawan baru dilakukan dengan cara mereka diberikan seorang mentor yang telah berpengalaman, dan karyawan baru mengikuti dan mendampingi mentor mereka dalam menyelesaikan tugas, dan biasanya masa pelatihan ini bisa berlangsung cukup lama sampai karyawan baru tersebut ahli dalam melakukan tugasnya.

Sedangkan sesi pelatihan lanjutan atau upgrade kemampuan dalam perusahaan ini tidak dilakukan karena biasanya setiap orang melakukan tugas yang sama selama mereka bekerja pada perusahaan kecuali hanya untuk beberapa orang ada yang dipindahkan atau berganti tugas namun kemampuan itu dimiliki karena ketika awal usaha berdiri satu orang karyawan bisa melakukan beberapa jenis pekerjaan. 


\section{c. Visi dan Misi Perusahaan}

Perusahaan menggunakan pendekatan informal dan sistem pengendalian manajemen, tidak terlalu terlihat pengendalian formal terjadi dalam setiap transaksi atau kegiatan. Dalam hal visi misi pun pemilik perusahaan hanya mengungkapkan bahwa perusahaan bertujuan untuk tetap bertahan, dan mensejahterakan keluarga dan karyawan.

\section{d. Bentuk Fisik Bangunan}

Dalam penataan fisik bangunan perusahaan "ABC" tidak terlalu memilki ciri khusus, ciri khusus yang dimiliki adalah logo dengan ciri khas abjad pertama dari nama pemilik, sedangkan untuk penataan tempat, warna ruangan maupun desain tertentu pemilik tidak terlalu memprioritaskan hal ini disebabkan oleh perusahaan ini lebih fokus untuk mendistribusikan produk mereka kepada pedagang usaha yang sama. perusahaan "ABC" juga tidak memiliki peraturan khusus dalam menetapkan aturan pakaian karyawan nya, hal ini dikarenakan sifat tenggang dan memahami sebagai keluarga dimana setiap orang diyakini memahami batas dan ukuran dalam berlaku "sopan" (dimaa langik di junjuang disitu bumi diinjak) sehingga dalam peraturan yang berjalan dilapangan banyak dilakukan dengan pendekatan kekeluargaan.

\section{Pengendalian Proses}

\section{a. Struktur Organisasi}

Struktur organisasi Pengelolaan sekarang secara struktur belum ada tertulis dan terorganisasi dengan baik, masih menggunakan sistem kekeluargaan. masih ada generasi kedua ikut dalam usaha mendampingi generasi ke 3 biasanya bagian produksi. Generasi ketiga mulai fokus usaha sejak 5 tahun belakangan. Sebelumnya sudah membantu juga tetapi sekedarnya saja.

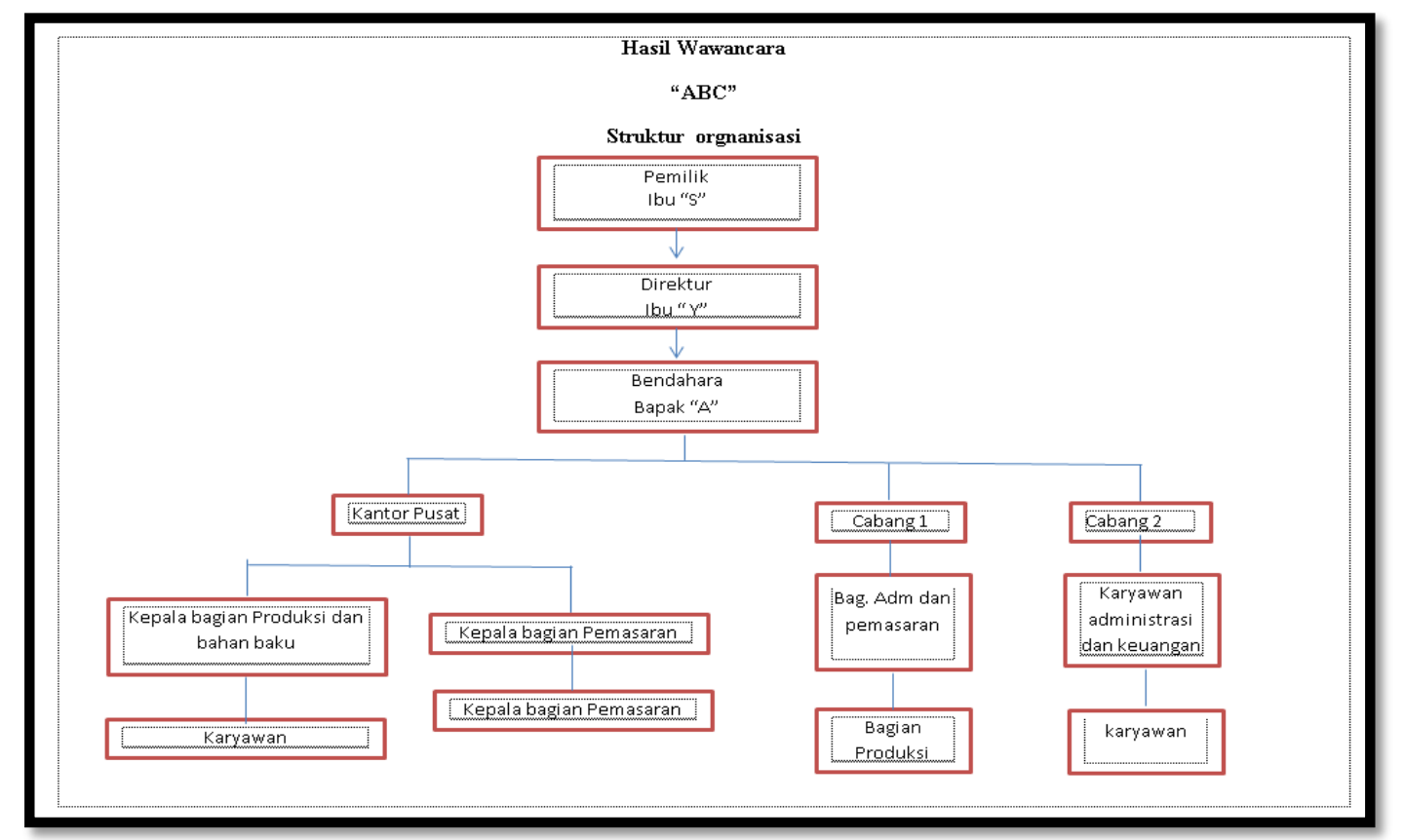

sumber : hasil pengolahan penulis 


\section{b. Sistem Reward dan Punishment}

Bentuk dan kriteria pemberian reward diberbagai perusahaan berbeda-beda. Diantaranya berdasarkan posisi jabatan, masa kerja, mencapai target tertentu. Reward terjadi dalam dua bentuk: full participation plan (reward bagi karyawan yang bekerja ekstra sehingga menghasilkan produksi tambahan) dan group incentive plan ( reward yang diberikan kepada sekelompok karyawan apabila mereka dapat bekerja dan menunjukkan hasil yang menguntungkan). Pemberian reward sendiri kepada karyawan dapat berupa bentuk finansial (gaji, komisi, bonus) dan non finansial (jaminan asuransi jiwa, pengobatan, jaminan hari tua,dll) (Merchant, 2012)

Sistem reward dalam perusahaan $\mathrm{ABC}$ reward diberikan pada karyawan berupa reward finansial pada saat lebaran seperti tunjangan hari raya, dan ada juga masanya ketika permintaan meningkat karyawan meminta dinaikkan gaji, dan baisanya pemilik memenuhi permintaan karyawan. Sedangkan punishment dapat berupa sanksi berat, sanksi sedang dan sanksi ringan. Punishment dapat dikategorikan menjadi dua punishment preventif (dimaksudkan agar tidak terjadi pelanggaran dapat berupa : tata tertib, anjuran dan perintah, larangan, paksaan, disiplin) dan punishment represif (dilakukan karena adanya pelanggaran dapat berupa: pemberitahuan, teguran, peringatan, hukuman) (Merchant, 2012). Penerapan punishment represif, dalam perusahaan $\mathrm{ABC}$ sangat jarang dilakukan, karena dalam menyelesaikan masalah digunakan pendekatan kekeluargaan atau lebih banyak pada punishment bersifat preventif. Sedangkan penerapan punishment represif juga diterapkan, namun tidaklah terlalu sering. Ketika ditemukan karyawan yang tidak jujur dilakukan pemanggilan dan beri peringatan, peringatan pertama, peringatan kedua dan kalau tidak berubah biasanya pada panggilan ketiga karyawan tersebut diberhentikan.

\section{c. Prosedur Keuangan dan Akuntansi}

Prosedur keuangan dan akuntansi pada perusahan $\mathrm{ABC}$ berpusat pada bendahara umum yaitu bapak "FD" yang merupakan adik kandung dari ibu "C", setiap cabang dan kantor pusat memiliki satu orang karyawan bagian pembukuan dan pencatatan serta merangkap menjadi kasir, setiap hari minimal jam 10 malam semua transaksi dalam sehari dilaporkan kepada bapak "FD", untuk beberapa transaksi yang bersifat online atau beberapa kerjasama tetap yang dilakukan perusahaan baik dengan toko lain maka uang transaksi langung ditransfer kerekening perusahaan yang dipegang oleh bapak "FD".

\section{KESIMPULAN DAN KETERBATASAN \\ Kesimpulan}

Penelitian ini telah menjelaskan hubungan antara gaya kepimpinan dan sistem pengendalian manajamen pada perusahaan etnis Minangkabau. Penelitian ini memiliki satu pertanyaan penelitian bagaimana pengaruh social budaya pengusaha Minangkabau terfleksi dalam penerapan Sistem Pengendalian Manajemen dan kepemimpinan pada perusahaan keluarga? Pertanyaan ini digunakan untuk melihat pemahaman dan penerapan sistem pengendalian manajamen pada bisnis keluarga yang dimiliki dan dikelola oleh keluarga etnis minangkabau. Sistem pengendalian manajemen yang diterapkan pada bisnis keluarga ABC menggunakan pendekatan informal, dengan gaya kepemimpinan yang diterapkan oleh pimpinan perusahaan adalah suportif. 
Penelitian ini merupakan penelitian menggunakan pendekatan kualitatif interpretatif dengan menggunakan lensa antropolofi emik dan etik. Dalam konteks budaya kepemimpinan pada perusahaan $\mathrm{ABC}$ dipengaruhi oleh nilai-nilai pribadi ibu "C". Nilai-nilai pribadinya berasaal dari budaya Minangkabau dan nilai-nilai Islam. Penelitian ini menjelaskan bahwa budaya perusahaan tidak sepenuhnya diciptakan oleh ibu "C" namun banyak diambil dan dipengaruhi oleh budaya Minangkabau yang pada umumnya masyarakat setempat khususnya karyawan perusahaan $\mathrm{ABC}$ telah menerapkan nilai adat dan agama ini dalam kehidupan.

Karakteristik kepemimpinan ibu "C" menggunakan nilai tungku tigo sajarangan (Tagak samo tinggi duduak samo randah dan nilai dimaa langik dijunjuang disinan bumi diinjak) serta nilai agama yang diserap kedalam adat yaitu Adat basandi syarak, syarak basandi kitabullah dalam nilai syari'ah Islam. Kesesuaian budaya antara pemilik dan karyawan yang kebanyakan merupakan anggota keluarga menciptakan organisasi yang stabil. Sehingga penerapan sistem pengendalian manajemen tidak dipakasakan oleh pemilik tetapi dinegosiasikan dan disesuaikan dengan budaya umum yang telah diterapkan pada masyarakat setempat terutama karyawan. Budaya yang sama membuat komunikasi lebih mudah dan memungkinkan meminimalkan konflik didalam perusahaan baik antara karyawan dengan pimpinan maupun karyawan dengan karyawan.

Penelitian ini mendukung penelitian Efferin dan hartono (2015), Ansari dan bell (1991) dan Tsamenyu (2008) bahwa budaya masyarakat merupakan pusat dalam pelaksanaan sistem pengendalian manajemen dalam bisnis keluarga. Namun, dalam penelitian ini nilai-nilai sistem pengendalian manajemen dipengaruhi kuat oleh nilai-nilai budaya Minangkabau. Dalam penelitian Efferin dan Hartono (2015) tidak ditemukannya dikotomi pemisahan dalam sistem infomal dan formal dalam perusahaan keluarga etnis China di Indonesia namun dalam penelitian ini, pemisahan antara kontrol informal dan formal dijalankan secara bersamaan oleh perusahaan dan pimpinan perusahaan. Sehingga penerapan pengendalian hasil, pengendalian proses dan pengendalian budaya diterapkan dengan beberapa kontrol yang bisa memiliki sifat kontrol yang berbeda sesuai dengan kebutuhan (dimaa langik dijunjuang disinan bumi diinjak).

\section{Keterbatasan}

Penelitian ini memeliki keterbatasan yaitu perusahaan yang diteliti hanya 1 perusahaan keluarga, sehingga tidak terlihat secara keselurahan apakah penerapan sistem pengendalian manajemen pada bisnis yang dikelola oleh keluarga minangkabau memiliki nilai yang sama. Sehingga penelitian lebih lanjut perlu dilakukan untuk melihat perbedaan penerapan, aspek budaya lain yang mempengaruhi serta agar ada pembanding antara bisnis keluarga dalam negara berkembang secara lebih global dengan cakupan lebih luas. 